\title{
A Rare Case of Renal Tumour: Metanephric Adenoma
}

\author{
Nadir Görülen Bir Renal Tümör Olgusu: Metanefrik \\ Adenom
}

Olgu Sunumu Case Report

Alındığı tarih: 21.10 .2018

Kabul tarihi: 10.12 .2018 Online Yayın tarihi: 29.08.2019

Mert Hamza Özbilen Tepecik Eğitim ve Araştırma Hastanesi, Üroloji Kliniği, Izmir - Türkiye

merthozbilen@hotmail.com ORCID: 0000-0002-5733-6790

M.Z. Keskin 0000-0002-9206-5586

Y.ö. İlbey 0000-0002-1483-9160 Tepecik Eğitim ve Araştırma Hastanesi, Üroloji Kliniği, Izmir, Türkiye

N. Güney 0000-0002-2792-4479 Tepecik Eğitim ve Araştırma Hastanesi, Patoloji Kliniği, İmir, Türkiye

Cite as: Özbilen MH, Keskin MZ, Güney N, Illbey YÖ. A rare case of renal tumour: Metanephric YO. A rare case of renal tumour: Metanephric
adenoma. Tepecik Eğit. ve Araşt. Hast. Dergisi. adenoma. Tepecik
Mert Hamza Özbilen $\odot$, Mehmet Zeynel Keskin $\odot$, Neslihan Güney $\odot$, Yusuf Özlem İlbey $\odot$

\begin{abstract}
Metanephric adenoma is a rare type of benign renal tumour that is encountered mostly in adult females and rarely in children. To this day, the imaging characteristics of the tumour have not been clearly defined. In this study, we have presented one of our patients in order to analyze metanephric adenoma with regard to its clinical symptoms, imaging, pathology, diagnosis, and treatment.

$M A=$ metanephric adenoma, $M R I=$ magnetic resonance imaging, $A B P=$ Arterial Blood Pressure, $P R C C=$ Papillary renal cell carcinoma, $W T=$ wilms tumour, $R A=$ renal adenoma, $C T=$ computed tomography, $C D=$ cluster of differentiation; $E M A=$ epithelial membrane antigen, $A M A C R=\alpha$-methylacyl-CoA racemase, TTF $=$ thyroid transcription factor-1, CK = cytokeratin; + = positive, - = negative
\end{abstract}

Keywords: metanephric adenoma, benign tumour, biopsy

Öz

Metanefrik adenom daha çok yetişkin kadınlarda ve nadiren çocuklarda görülen nadir bir benign böbrek tümörüdür. Günümüze kadar, tümörün görüntüleme özellikleri net bir şekilde tanımlanmıştır. Biz bu çalışmada, metanefrik adenomlu bir hastamızı metanefrik adenomun klinik bulgularını, görüntüleme, patoloji, tanı ve tedavisini analiz etmek amaciyla sunduk.

$M A=$ metanefrik adenom, $M R G=$ manyetik rezonans görüntüleme, $T A=$ Arteriyel Tansiyon, PRHK = papiller renal hücreli kanser, $W T=$ wilms tümör, $R A=$ renal adenom, $B T=$ bilgisayarlı tomografi, $C D=$ cluster of differentiation; EMA = epitelyal membran antijeni, $A M A C R=\alpha$-methylacyl-CoA racemase, $T T F=$ tiroid transkripsiyon faktör $-1, C K=$ sitokeratin; + = pozitif, - = negatif

Anahtar kelimeler: metanefrik adenom, benign tümör, biyopsi

\section{INTRODUCTION}

Metanephric adenoma (MA) is a rare benign neoplasm of the kidney that is usually encountered in middle-aged females, with few cases reported in children ${ }^{(1)}$. Only $0.2 \%$ of adult renal epithelial tumours are diagnosed as MA (2). The preoperative diagnosis of this benign tumour is usually difficult radiologically; however, accurate diagnosis is of great importance to avoid unnecessary radical surgery ${ }^{(1)}$. In this study, a case was presented with immunohistochemical and radiographic findings for the characteristics of MA to be comprehended more clearly.

\section{CASE PRESENTATION}

A 39-year-old female patient presented to our hospital due to right-side pain that had started 2 years ago and increased in severity from time to time. Evaluation of a non-contrast computed tomography (CT) scan obtained 2 years prior to the patient's presentation revealed a $10 \mathrm{~mm}$ stone localized in the middle region of the right kidney and a $45 \times 32 \mathrm{~mm}$ solid lesion in the lower pole (c) Telif hakkı T.C. Sağlık Bakanlığı İmir Tepecik Eğit. ve Araşt. Hastanesi. Logos Tıp Yayıncılık tarafindan yayınlanmaktadır. Bu dergide yayınlanan bütün makaleler Creative Commons Attf-GayriTicari 4.0 Uluslararası Lisansı ile lisanslanmıştr.

(c) Copyright Association of Publication of the T.C. Ministry of Health Izmir Tepecik Education and Research Hospital. This journal published by Logos Medical Publishing. Licenced by Creative Commons Attribution-NonCommercial 4.0 International (CC BY-NC 4.0) 
of the right kidney that had a slightly hyperdense appearance compared with the parenchyma and an intraparenchymal localization (Figure 1).

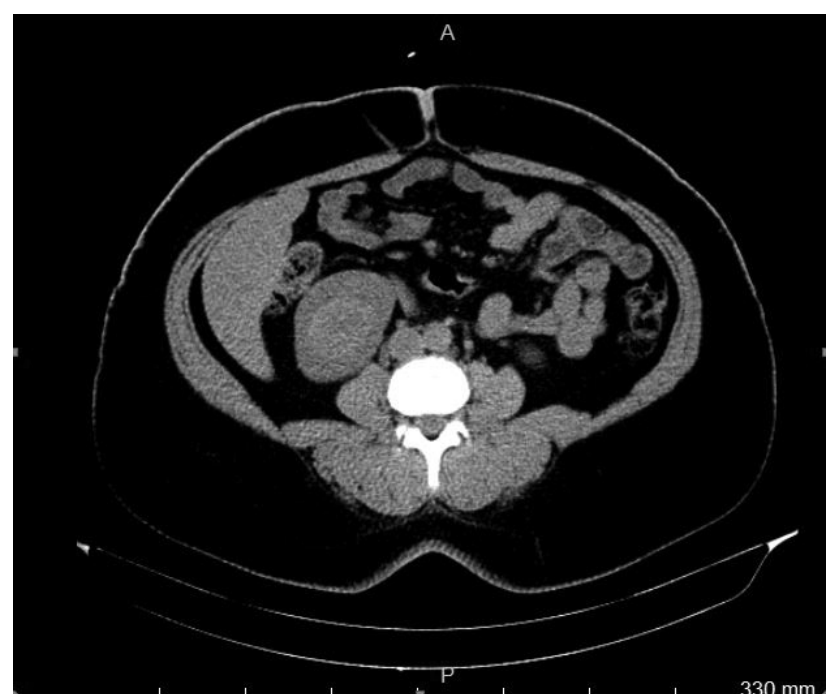

Figure 1. Non-contrast abdominal CT scan of a $45 \times 32 \mathrm{~mm}$ solid lesion in the lower pole of the right kidney with a slightly hyperdense appearance compared with the parenchyma and anintraparenchymal localization.

It was found that the patient had undergone 4 sessions of extracorporeal shock wave lithotripsy (ESWL) in the 2 years that followed, however the stone could not be fragmented. The general condition of the patient was good when she presented to our clinic for right-side pain. She did not have any other symptoms than a right-side pain that had persisted for 2 years and increased in severity from time to time, and did not present any abnormal findings in the physical examination. She did not have family history. The ABP of the patient was $110 / 75 \mathrm{mmHg}$. Some laboratory test results were as follows: hemoglobin, $12.5 \mathrm{~g} / \mathrm{dl}$, white blood cell count, $10300 / \mu \mathrm{L}$, BUN, $27 \mathrm{mg} / \mathrm{dL}$, and serum creatinine, $0.8 \mathrm{mg} / \mathrm{dL}$. The CT urography taken at the time of admission demonstrated an image consistent with a $12 \mathrm{~mm}$ stone in the right renal pelvis, immediately anterior to the ureteropelvic junction, and revealed a $44 \times 35$ $\mathrm{mm}$ mass lesion with a parenchymal localization at the level of the lower pole of the right kidney that distorted the lower pole collecting system which was slightly hyperdense in pre-contrast imaging (Figure 2).

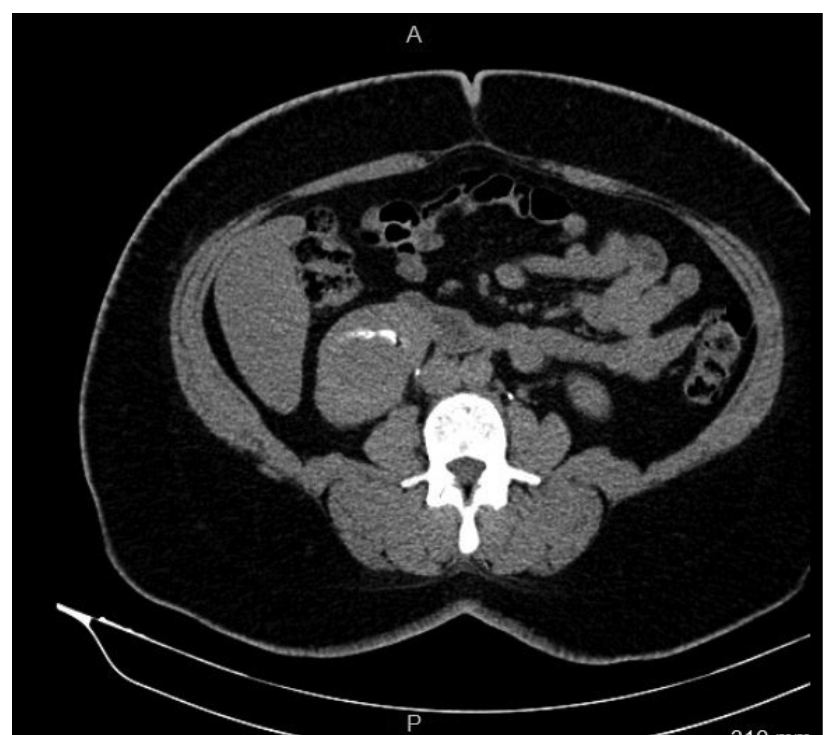

Figure $2.44 \times 35 \mathrm{~mm}$ massive lesion with a parenchymal localization at the level of the lower pole of the right kidney that distorts the lower pole collecting system and was slightly hyperdense in pre-contrast imaging.

The thoracic CT obtained for screening purposes did not demonstrate lymph nodes or findings of metastasis. Contrast-enhanced abdominal magnetic resonance imaging (MRI) scan obtained subsequently revealed a nodular appearance of $27 \times 30 \mathrm{~mm}$ size that was localized in the middle zone-lower pole of the right kidney, characterized by a hypointense appearance compared with the normal parenchyma in T1A series and an isointense appearance in T2A series, with less contrast enhancement than the renal parenchyma in postcontrast series (Figure 3).

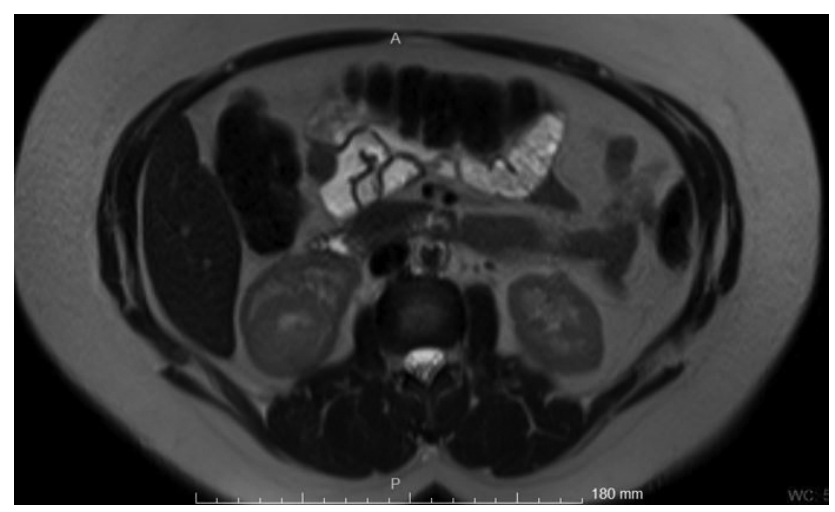

Figure $3.27 \times 30 \mathrm{~mm}$ nodular appearance in the middle zone-lower pole of the right kidney as demonstrated by dynamic contrast magnetic resonance imaging (MRI). 


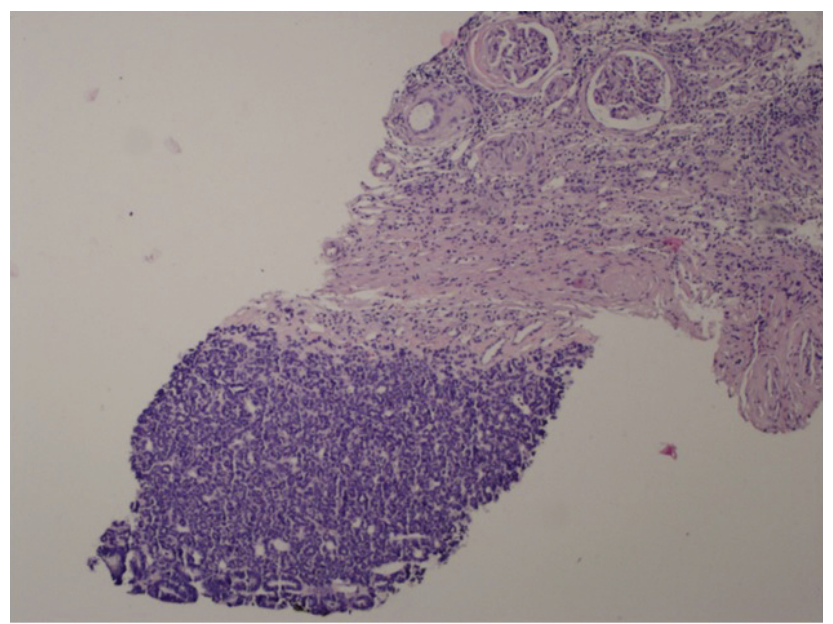

Figure 4. H \& E x10 magnification, adjacent to kidney parenchyma with metanephric adenoma.

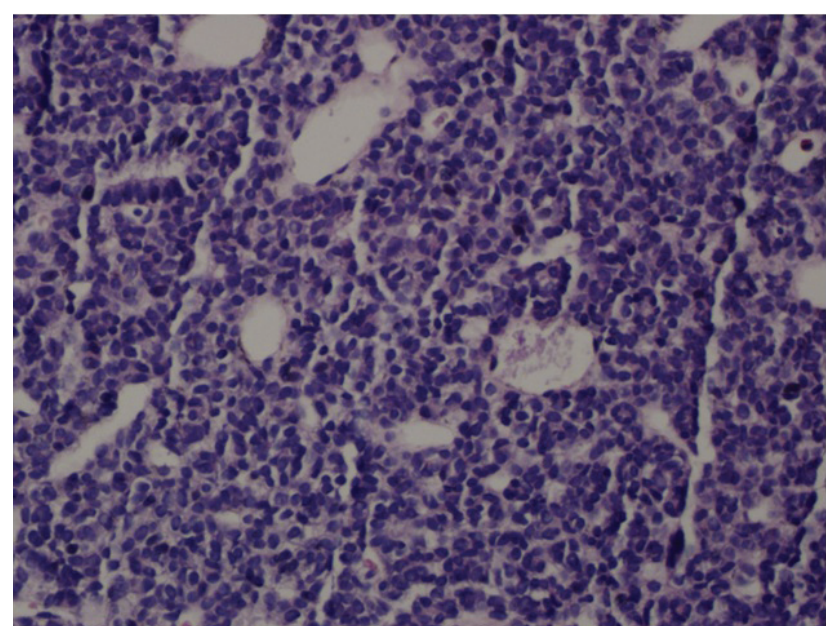

Figure 5. x40 magnification.

The lesion was considered stable when compared with findings of CT scan taken two years ago. As the current images do not allow a benign-malign differentiation, evaluation with Tru-cut biopsy was considered appropriate. Microscopy of the biopsy revealed a benign tumoural lesion that was comprised of pale eosinophilic cells with scant cytoplasm that constituted tightly packed small, uniform, round acini in scant edematous stroma; small, round, uniform nuclei with delicate chromatin but without nucleoli. Mitotic activity was not detected. The immunohistochemical panel showed pankeratin, vimentin, and CD 57 positivity, weak-moderate WT-1 nuclear staining, and Ki-67 nuclear staining at a rate of $1-2 \%$. Staining with cytokeratin 7 , cytokeratin 20 , chro-

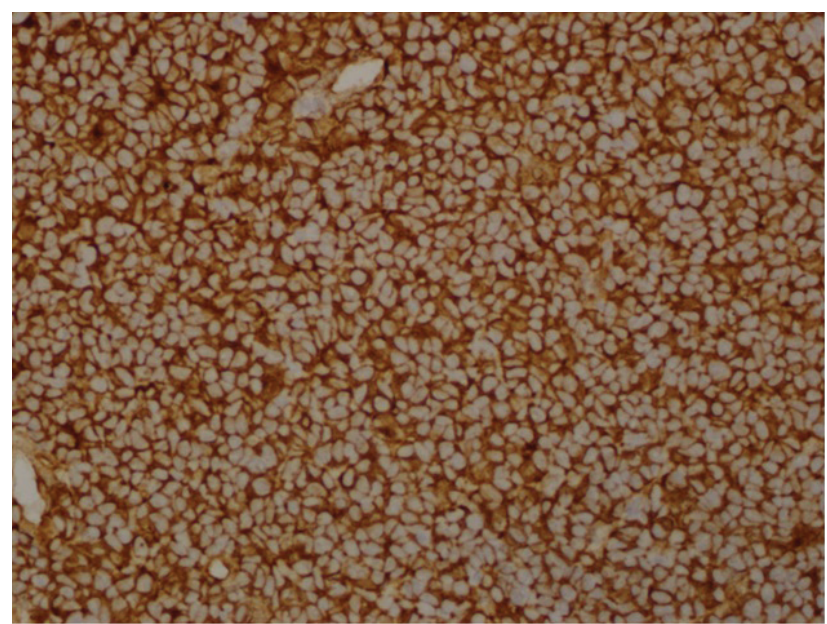

Figure 6. CD57, diffuse positive stained in tumor.

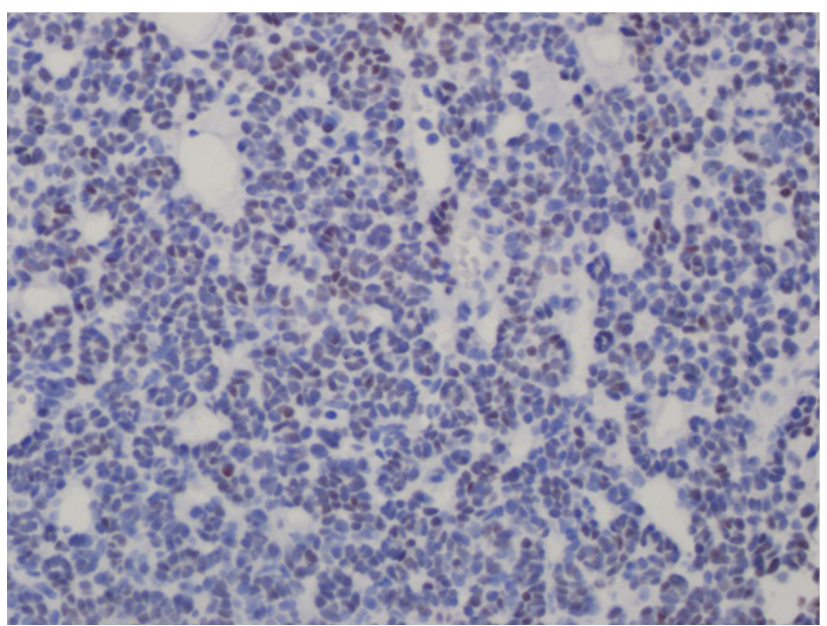

Figure 7. WT1, focal positive stained in tumor.

mogranin, synaptophysin, TTF-1, EMA, and CD56 was not seen (Figure 4,5,6,7). The pathological report confirmed that the lesion in the right kidney was consistent with MA.

\section{DISCUSSION}

Metanephric adenoma is a rare benign epithelial tumour of the kidney, comprising $0.2 \%$ of all renal neoplasms, and is encountered two times more frequently in females ${ }^{(3,4)}$. Although metanephric adenoma is usually benign, some cases of metastatic disease have been reported ${ }^{(5-7)}$. Pins et al. ${ }^{(5)}$ reported three metanephric adenoma-like metastatic tumours, however, they described certain histological proper- 
ties that allowed these tumours to be differentiated from metanephric adenoma. Patients with metanephric adenoma are usually asymptomatic or present with nonspecific clinical symptoms. Most cases are detected incidentally during imaging performed for other complaints ${ }^{(8)}$. Similarly, our patient was detected incidentally. In different cases, the signs and symptoms of metanephric adenoma may include polycythemia or erythrocytosis, abdominal or flank pain, hematuria, hypertension, fever, and a palpable mass. Among these, polycythemia was shown by several studies to be closely related to metanephric adenoma and a higher incidence was reported for metanephric adenoma compared to other disorders of the kidney ${ }^{(9)}$.

Clinical and diagnostic considerations require metanephric adenoma to be distinguished from Wilms tumour, oncocytoma, and papillary renal cell carcinoma (PRCC). The mean size of MA varies between 4.7 and $5.5 \mathrm{~cm}$; however, sizes up to $20 \mathrm{~cm}$ may be encountered ${ }^{(9,10)}$. Radiologically, MA demonstrates hypovascularity in contrast CT; however, Wilms tumour and PRCC also present similar features ${ }^{(10)}$. In T2-weighted MRI, MA usually shows slow signal intensity which resembles PRCC findings. Thus, radiological evaluation is not sufficient for the diagnosis of metanephric adenoma, as demonstrated by our case. The difficulty of diagnosing metanephric adenoma without pathological evaluation is also linked to its rarity as a tumour. However, preoperative diagnosis is important to avoid excessive treatments such as neoadjuvant therapy. Two earlier studies have reported that biopsy can facilitate the diagnosis of metanephric adenoma ${ }^{(11)}$. We too have chosen to obtain a biopsy from our case. Macroscopically, the tumour has a tan-grey or yellow surface and a clear boundary ${ }^{(9,10)}$. In cytopathology, the differential diagnosis is primarily concerned with well-differentiated WT, the solid variant of PRCC, and RA. As opposed to well-differentiated WTs, MAs lack nuclear atypia and/or mitotic figures. As opposed to PRCC, MAs do not consist of foamy or hemosiderin-laden macrophages, fibrovascular cores, or nuclear atypia.
RA is a benign lesion with a round nucleus that can resemble MA and is characterized by uniform cells with scant cytoplasm ${ }^{(12)}$.

The results of the studies that have been conducted up to now have revealed that the immunohistochemical staining pattern of MA facilitates its differentiation from PRCC and WT ${ }^{(13,14)}$. The results indicate WT1, CD57, and AMACR as useful markers for the differentiation of MA from PRCC. However, immunohistochemical methods are not as useful in differentiating MA from WT. In this case, morphological parameters such as presence of necrosis, atypia, and a high mitotic index are more favourable (15). MA usually stains positively for WT1 and CD57, and negatively for CD56, AMACR, and CK7. On the other hand, PRCC stains positively for AMACR, and CK7, and may be negatively for WT1, CD57, and CD56. Well-differentiated WTs show WT1 and CD56 reactivity and usually no reactivity for CD57, AMACR, and CK7. RAs usually give positive results with cytokeratin and epithelial membrane antigen (EMA). The immunohistochemistry panel of our case is differentiated from PRCC by staining positively with CD57+ and WT-1+; negatively with cytokeratin and EMA from RA; positively with CD57 staining from WT, lack of cytokeratin staining, and absence of mitosis.

\section{CONCLUSION}

MA is a rare renal tumour that does not possess specific imaging characteristics and its definitive diagnosis depends on histopathological evaluation. Most MAs manifest as well-defined, oval, cystic-solid or solid renal masses that may be accompanied by calcifications of various sizes, as well as necrotic and hemorrhagic regions. When a mass is considered very probably to be a MA, Tru-cut biopsy, clinical follow-up, or partial nephrectomy must be arranged. Further studies are needed to reveal the pathology, radiological findings, and biological behaviour of MA. 
Conflict of Interest: There is no conflict of interest related to any person and / or institution.

Informed Consent: Informed consent was taken from the patient.

Çıkar Çatışması: Herhangi bir kişi ve / veya kurumla ilgili herhangi bir çıkar çatışması yoktur.

Hasta Onamı: Hastadan bilgilendirilmiş onam alındı.

\section{REFERENCES}

1. Pasricha S, Gandhi JS, Gupta G, Mehta A, Beg S: Bilateral, multicenteric metanephric adenoma associated with Wilms' tumor in a child: A rare presentation with important diagnosticand therapeuticimplications. Int JUrol.2012;19:1114-7. [CrossRef]

2. Hwang SS and Choi YJ: Metanephric adenoma of the kidney: Case report. Abdom Imaging. 2004;29:309-11. [CrossRef]

3. Amin MB, Amin MB, Tamboli $P$, et al. Prognostic impact of histologic subtyping of adult renal epithelial neoplasms: An experience of 405 cases. Am J Surg Pathol. 2002;26:281-91. [CrossRef]

4. Jones EC, Pins $M$, Dickersin GR, Young RH. Metanephric adenoma of the kidney: A clinicopathological, immunohistochemical, flow cytometric, cytogenetic, and electron microscopic study of seven cases. Am J Surg Pathol. 1995;19:615-26. [CrossRef]

5. Pins MR, Jones EC, Martul EV, Kamat BR, Umlas S, Renshaw AA. Metanephric adenomalike tumors of the kidney: Report of 3 malignancies with emphasis on discriminating features. Arch Pathol Lab Med. 1999;123:415-20.

6. Nakagawa $\mathrm{T}$, Kanai $\mathrm{Y}$, Fujimoto $\mathrm{H}$, et al. Malignant mixed epithelial and stromal tumours of the kidney: a report of the first two cases with a fatal clinical outcome. Histopathology. 2004;44:302-4. [CrossRef]

7. Algaba F. Renal adenomas: pathological differential diagnosis with malignant tumors. Adv Urol. 2008:974848. [CrossRef]

8. Torricelli FCM, Marchini GS, Campos RSM, Gil AO. Metanephric adenoma: Clinical, imaging, and histological findings. Clinics. 2011;66:359-61. [CrossRef]

9. Davis CJ, Barton JH, Sesterhenn IA, Mostofi FK. Metanephric adenoma. Clinicopathological study of fifty patients. Am J Surg Pathol. 1995;19:1101-14. [CrossRef]

10. Jones EC, Pins M, Richard Dickersin G, Young RH. Metanephric adenoma of the kidney: A clinicopathological, immunohistochemical, flow cytometric, cytogenetic, and electron microscopic study of seven cases. Am J Surg Pathol. 1995;19:615-26. [CrossRef]

11. Terao $\mathrm{H}$, Matsumoto $\mathrm{T}$, Umemoto $\mathrm{S}$, Onuki $\mathrm{T}$, Kobayashi $\mathrm{K}$, Ohgo $Y$, Nogcchi S, Kishi H, Tsuura $Y$ and Nagashima $Y$. Metanephric adenoma: Report of two cases. Hinyokika Kiyo. 2008;54:599-602.

12. Renshaw AA, Maurici D, Fletcher JA. Cytologic and fluorescence in situ hybridization (FISH) examination of metanephric adenoma. Diagn Cytopathol. 1997;16:107-11. [CrossRef]

13. Muir TE, Cheville JC, Lager DJ. Metanephric adenoma, nephrogenic rests, and Wilms' tumor: a histologic and immunophenotypic comparison. Am J Surg Pathol. 2001;25:1290-6. [CrossRef]

14. Olgac S, Hutchinson B, Tickoo SK, Reuter VE. Alphamethylacyl-CoA racemase as a marker in the differential diagnosis of metanephric adenoma. Mod Pathol. 2006;19:218-24. [CrossRef]

15. Patel NP, Geisinger KR, Zagoria RJ, Bergman S. Fine needle aspiration biopsy of metanephric adenoma: a case report. Acta Cytol. 2009;53:327-31. [CrossRef] 